\title{
Cerebral Venous Sinus Thrombosis Presenting with Seizure in Pregnancy
}

\author{
Gebelikte Nöbet Geçirme Sonrasında Başvuran Serebral Sinüs Ven Trombozu
}

\author{
Hesna Bektaş', Murat Türkarslan², Nurettin Özgür Doğan³, Çiğdem Hacıfazlıŏglu4, Yunsur Çevik² \\ 'Department of Neurology, Keçiören Training and Research Hospital, Ankara, Turkey \\ 2Department of Emergency Medicine, Keçiören Training and Research Hospital, Ankara, Turkey \\ 32Department of Emergency Medicine, Atatürk Training and Research Hospital, Ankara, Turkey \\ ${ }^{4}$ Department of Radiology, Keçiören Training and Research Hospital, Ankara, Turkey
}

\section{ABSTRACT}

Introduction: Cerebral venous sinus thrombosis is a rare condition. The most frequent symptoms and signs are headache, focal seizures with or without secondary generalization, unilateral or bilateral paresis, and papilledema. We report a case of left transverse sinus and sigmoid sinus thrombosis that presented with seizure in a pregnant woman.

Case Report: A 31-year-old woman at 33 weeks of pregnancy was admitted with sudden onset of seizure to the emergency department. The magnetic resonance scan of her brain showed the presence of a cortical-subcortical infarction in the cerebellar hemisphere, and magnetic resonance venography ultimately revealed left transverse sinus and sigmoid sinus thrombosis. The patient was treated with phenytoin and enoxaparin; the fetus was delivered after an urgent cesarean section.

Conclusion: In pregnant women presenting with seizure, cerebral venous sinus thrombosis should be also considered in the differential diagnosis.

Keywords: Cerebral venous sinus thrombosis, pregnancy, emergency medicine

Received: 09.02.2013 Accepted: 07.05.2013

\section{ÖZET}

Giriş: Serebral sinüs ven trombozu nadir bir durumdur. En sık semptom ve bulgularl; sekonder jeneralizasyon gösteren ve göstermeyen fokal nöbetler, tek veya çift taraflı güçsüzlük ve papilödemdir. Bu olguda, nöbet geçirme sonrasında başvuran gebe bir kadında saptanan sol transvers ve sigmoid sinüs trombozunu sunuyoruz.

Olgu Sunumu: Gebeliğinin 33. haftasında olan, 31 yaşında kadın hasta acil servise nöbet şikayeti ile başvurdu. Beyin manyetik rezonans görüntülemesinde; serebellar hemisferlerde kortikal subkortikal enfarkt ile manyetik rezonans venografide sol transvers sinüs ve sigmoid sinüs trombozu saptandı. Hasta fenitoin ve enoksaparinle tedavi edildi; fetüs ise acil sezaryen girişimi sonrasında doğurtuldu.

Sonuç: Nöbet sonrasında başvuran gebe kadın hastalarda, serebral sinüs ven trombozu da ayırıcı tanıda düşünülmelidir.

Anahtar Kelimeler: Serebral sinüs ven trombozu, gebelik, acil tıp Geliş Tarihi: 09.02.2013 Kabul Tarihi: 07.05.2013

\section{Introduction}

Cerebral venous sinus thrombosis (CVST) is a relatively rare subtype of stroke $(1,2)$. The most frequent symptoms and signs are headache (95\%), focal seizures with or without secondary generalization (47\%), unilateral or bilateral paresis (43\%), and papilledema (41\%) (3). Risk factors indicating CVST include local infections (middle ear or facial skin infections), thrombophilic states (factor V Leiden gene mutation; deficit of antithrombin III, protein C, and protein S; hyperhomocysteinemia with or without elevated factor VIII levels; and antiphospholipid syndrome), systemic inflammatory diseases, oral contraceptives, and puerperium (4).

The association of CVST with pregnancy and puerperium has been relatively well known. CVST risk is maximal during the first month in the puerperal period and increases with maternal age, multiparity, increasing hospital size, home deliveries, cesarean delivery, hypertension, infection, dehydration, excessive vomiting, and anemia (5). 
Seizure is an atypical presentation for pregnancy-related CVST. We report a case of left transverse sinus and sigmoid sinus thrombosis that presented with seizure in a pregnant woman who was in her third trimester.

\section{Case Report}

A 31-year-old woman at 33 weeks of pregnancy was admitted to the emergency department (ED) for sudden onset of contraction of her body and urinary incontinence. On the physical examination, her vital signs were stable; however, she was unconscious and unresponsive. The patient had generalized tonic-clonic seizures 2 times, which lasted about 1 minute during the ED observation. On neurologic examination, her Glasgow Coma Scale score was 11 after the seizure activity ended, neck stiffness was negative, and light reaction of the pupils was positive. The four extremities were responsive to painful stimulus after the first seizure activity in the ED ended, and her Babinski sign was bilateral negative. In her history, she did not have any seizure activities before and had a healthy pregnancy period during the 33-week period. Her relatives denied that she had any medical illnesses or systemic conditions, including epilepsia, stroke, or any drug use or abuse (also, no oral contraceptive drug use before pregnancy).

The patient was treated with supplemental oxygen, and intravenous diazepam was given when the seizure activity occurred. The second seizure lasted 5 minutes. One hour after the initial assessment, the patient was completely awake, and the neurological examination was repeated. She did not have any motor weaknesses and sensory deficits and her speech was normal, but she failed to complete the cerebellar tests, including the finger-to-nose test and had ataxia and significant gait disturbance. Her complete blood count, liver, renal function, and thyroid function tests were in the normal ranges, and her electrocardiography revealed a normal sinus rhythm with a rate of 85 per minute.

She was referred to the neurology department, and $18 \mathrm{mg} / \mathrm{kg}$ phenytoin was given in 40 minutes. After controlling of the patient's seizure, magnetic resonance imaging (MRI) and magnetic resonance venography of brain were done. MRI showed an infarction at the bilateral cortical and subcortical areas of the cerebellum (Figure 1), and venography showed thrombosis of the left transverse and sigmoid sinuses (Figure 2)

Low-molecular-weight heparin was added to the phenytoin regimen for venous sinus thrombosis. She consulted the obstetrics department, and the result of the obstetric ultrasound revealed a 1400-g fetus with reduced movements in the uterus. Therefore, an urgent cesarean delivery was performed, and a healthy baby weighing $1300 \mathrm{~g}$ was delivered and admitted to the neonatal intensive care unit.

After she was admitted to the obstetrics department, detailed tests for thrombophilia were ordered, including anti-nuclear antibody (ANA), anti-mitochondrial antibody (AMA), anti-smooth muscle antibody (ASMA), and anti-liver kidney microsomal antibody (anti-LKM), which were found in the normal ranges. Also, her anti-ds DNA level was $7.70 \mathrm{IU} / \mathrm{mL}$ (normal: $20-25 \mathrm{IU} / \mathrm{mL}$ ), and the homocysteine level

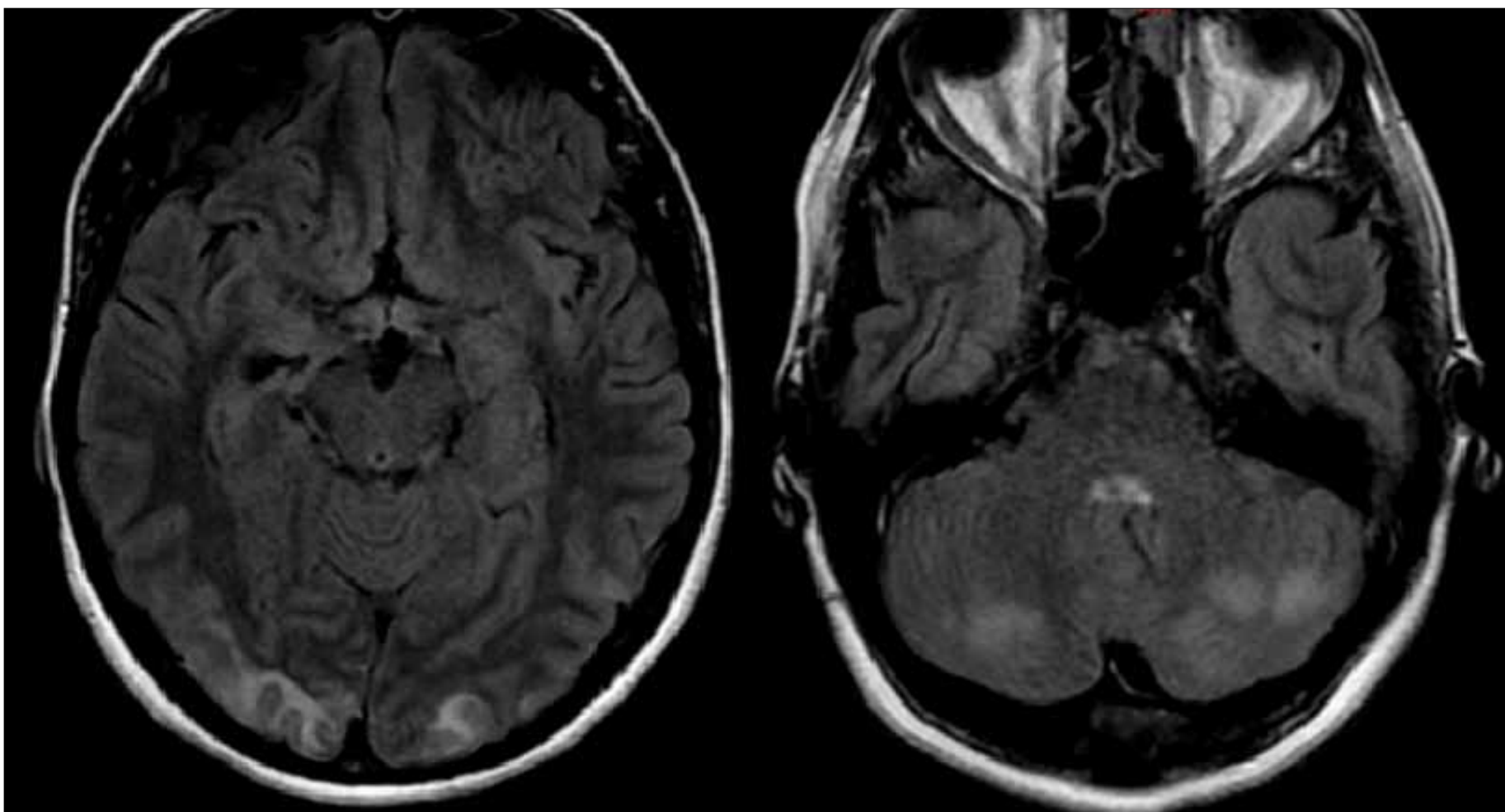

Figure 1. Axial fluid-attenuated inversion recovery (FLAIR) magnetic resonance imaging revealed hyperintensity in both occipital lobes and cerebellar hemispheres 

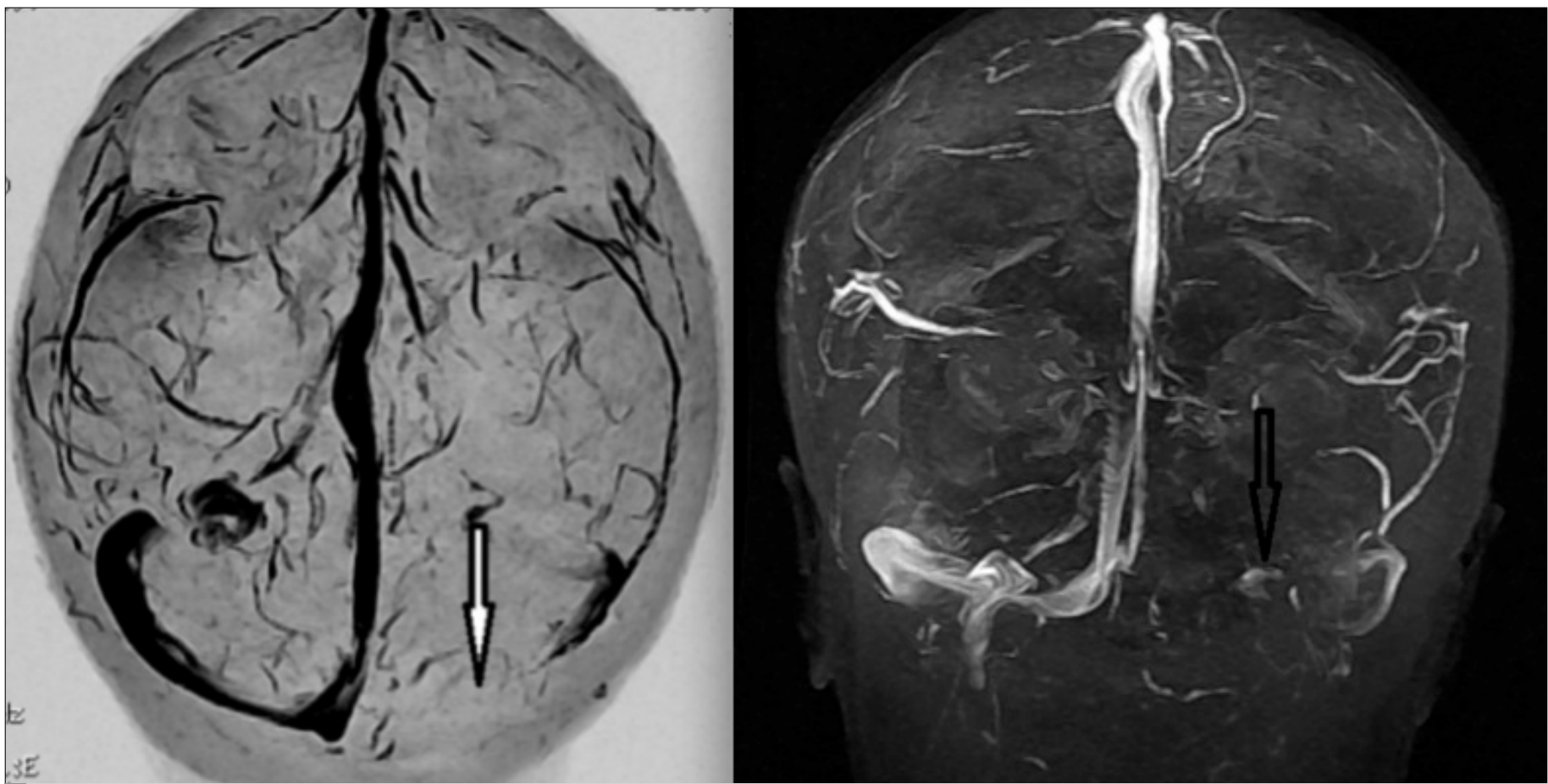

Figure 2. Two-dimensional time-of-flight (2D-TOF) magnetic resonance venography revealed thrombosis in left transvers sinus (white and black arrows)

was $10.8 \mu \mathrm{mol} / \mathrm{L}$ (normal: 0-12 $\mu \mathrm{mol} / \mathrm{L}$ ). Her transthoracic echocardiography and Doppler ultrasonography for carotid-vertebral arteries did not reveal abnormal results. She did not have any postoperative problems and was discharged home 1 week after cesarean delivery. Anticoagulant therapy was continued, and folic acid was added.

\section{Discussion}

Cerebrovascular accidents during pregnancy have increased the risk of maternal, fetal, and other neurological complications. This increased tendency for hypercoagulability may be attributed to some hormonal changes (6). Cerebral venous thrombosis is a rare variety of cerebrovascular accident that involves cerebral veins and dural sinuses of the brain (5). The frequency of peripartum CVST is approximately 11.6 cases per 100,000 deliveries in Western countries, although exact data for Asian countries are limited (7). Although major signs and symptoms of ischemic conditions in pregnancy are well defined, CVST symptoms could be indistinct and highly variable.

Seizure or status epilepticus is a remarkable presentation for cerebral venous thrombosis (approximately 40\%); also, the incidence is far higher than in patients with arterial stroke (1). The most frequent but least specific symptom of CVST is severe headache, which is present in more than $90 \%$ of adult patients. It could be increased gradually over a couple of days or suddenly, mimicking a subarachnoid hemorrhage (8). Our patient did not have any prodromal symptoms, such as headache, nausea, or vomiting. The initial symptom was a generalized tonic-clonic seizure, which occurred also 2 times in the ED.
Simultaneously, existence of an infarction in the occipital and cerebellar areas was also a confounding factor in our patient. Wasay et al. investigated major differences between cerebral venous thrombosis and arterial ischemic stroke in young Asian women. They found that age under 36 years, anemia, pregnancy or postpartum state, and presence of hemorrhagic infarcts on the computed tomography scan or magnetic resonance imaging were significant predictors of CVST. On the other hand, age over 36 years, diabetes, hypertension, dyslipidemia, recent myocardial infarction, and electrocardiographic abnormalities were strong predictors for acute ischemic stroke (9).

In young patients with ischemic stroke or CVST, existence of a genetic predisposition or underlying disorder should be determined, if possible. Coutinho et al. reported genetic thrombophilia in 22\% and acquired prothrombotic condition in 16\% of women with CVST (10). We also investigated the source of the ischemic/thrombophilic state in our patient; however, no significant cause for ischemic stroke and CVST was found, as the literature indicated. Usually, an obvious reason can not be determined in young patients who experience an ischemic stroke or CVST, like our patient.

Pregnancy and, particularly, the peripartum period carry important risks for hypercoagulability and related complications. Cerebral venous sinus thrombosis is a rare condition; however, it should be diagnosed and properly treated. Diagnostic pitfalls may be overcome with liberal use of magnetic resonance venography and other radiological modalities.

Informed Consent: Written informed consent was obtained from the patient who participated in this study 
Peer review: Externally peer-reviewed.

Author contributions: Concept - H.B.; Design - N.Ö.D, M.T.; Analysis and/or Interpretation - N.Ö.D.; Literature Review - H.B., Ç.H., N.Ö.D.; Writer - N.Ö.D.; Critical Review - Y.Ç.

Conflict of Interest: The authors declared no conflict of interest.

Financial Disclosure: The authors declared that this study has received no financial support.

Hasta Onamı: Yazıı ıasta onamı bu çalışmaya katılan hastadan alınmıştır.

Hakem değerlendirmesi: Dış bağımsız.

Yazar Katkıları: Fikir - H.B.; Tasarım - N.Ö.D, M.T.; Analiz ve/veya yorum - N.Ö.D.; Literatür taraması - H.B., Ç.H., N.Ö.D..; Yazıyı yazan - N.Ö.D.; Eleştirel İnceleme - Y.Ç.

Çıkar Çatışması: Yazarlar herhangi bir çıkar çatışması bildirmemişlerdir.

Finansal Destek: Yazarlar bu çalışma için finansal destek almadıklarını beyan etmişlerdir.

\section{References}

1. Stam J. Thrombosis of the cerebral veins and sinuses. N Engl J Med 2005; 352: 1791-8. [CrossRef]

2. Bousser MG, Ferro JM. Cerebral venous thrombosis: an update. Lancet Neurol 2007; 6: 162-70. [CrossRef]

3. de Bruijn SF, de Haan RJ, Stam J. Clinical features and prognostic factors of cerebral venous sinus thrombosis in a prospective series of 59 patients. J Neurol Neurosurg Psychiatry 2001; 70: 105-8. [CrossRef]

4. Munira Y, Sakinah Z, Zunaina E. Cerebral venous sinus thrombosis presenting with diplopia in pregnancy: a case report. J Med Case Rep 2012; 6: 336. [CrossRef]

5. Bousser MG, Crassard I. Cerebral venous thrombosis, pregnancy and oral contraceptives. Thromb Res 2012; 130 Suppl 1: S19-22. [CrossRef]

6. Ozucelik DN, Kunt MM, Karaca MA, Çobanoglu M. Intracerebral hemorrhage during pregnancy: Case report. AKATOS 2010; 1: 40-3.

7. Lanska DJ, Kryscio RJ. Risk factors for peripartum and postpartum stroke and intracranial venous thrombosis. Stroke 2000; 31: 1274-82. [CrossRef]

8. de Bruijn SF, Stam J, Kappelle LJ. Thunderclap headache as first symptom of cerebral venous sinus thrombosis. Lancet 1996; 348: 1623 5. [CrossRef]

9. Wasay M, Saadatnia M, Venketasubramanian N, Kaul S, Menon B, Gunaratne $P$, et al. Predictors of cerebral venous thrombosis and arterial ischemic stroke in young Asian women. J Stroke Cerebrovasc Dis 2012; 21: 689-94. [CrossRef]

10. Coutinho JM, Ferro JM, Canhão P, Barinagarrementeria F, Cantú C, Bousser MG, et al. Cerebral venous and sinus thrombosis in women. Stroke 2009; 40: 2356-61. [CrossRef] 